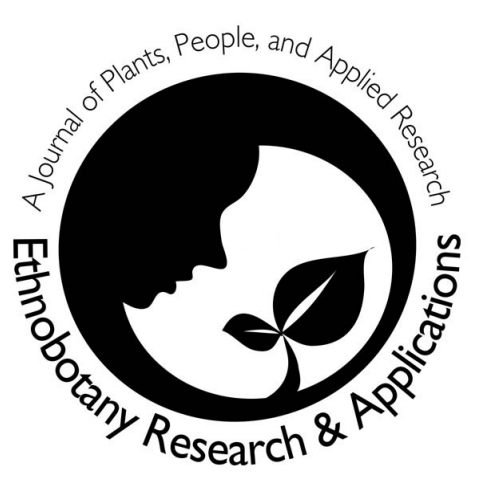

\title{
Fuelwood Consumption and Woody Biomass accumulation in Mali, West Africa
}

\author{
Jeff Morton
}

\section{Research}

\begin{abstract}
The narrative that human consumption of fuelwood has induced savannization in sub-Saharan Africa has had wide support for centuries. By the mid-1990s, however, some authors found evidence that undermined the fuelwoodsavannization theory. This project set out to add data to the debate by comparing fuelwood consumption to woody biomass accumulation in one village in Mali, West Africa. High, mean, and low fuelwood consumption rates were found to be 574,380 , and $291 \mathrm{~kg}$ per person per year respectively. Woody biomass accumulation was calculated at $1659.6 \mathrm{~kg} \mathrm{ha}^{-1}$ year $^{-1}$. Under the highest consumption rate, 0.35 ha of wooded land is needed to meet the fuelwood demand of one person. These figures, and evidence from observing fuelwood collection, undermine the notion that, at least in this region of Mali, fuelwood consumption is a driver of deforestation. The paper concludes by discussing forest management issues in the region and suggests areas for future research.
\end{abstract}

\section{Introduction}

Many researchers and development organizations hold the belief that human intervention has transformed much of sub-Saharan West Africa from a closed, dry tropical forest into landscapes that can support only woodlands (see Fairhead \& Leach 1996, Salzmann 2000, Steentoft 1988, White 1983). The theory of human-induced savannization can be found as early as the onset of Eurpoean occupation of Africa (Fairhead \& Leach 1996). In the later half of the 20th century, the narrative of dry forest-to-woodland conversion consistently included fuelwood collection and consumption as a root cause (e.g., Eckholm 1975). The idea that local people were deforesting their lands in order to supply themselves with fuelwood gained a following over time. Governmental and nongovernmental organizations alike have reported concerns over fuelwood-caused desertification and impending fuelwood crises (e.g., Maiga 1999, UNFAO 2001, USAID 2001). In response, strategies and programs have been developed to address the reported problem (e.g., De Troyer 1986, Millington et al. 1992, Sumberg \& Burke 1991).
In spite of its widespread acceptance, some authors came to question the link between fuelwood consumption and savannization. Research in the latter half of the 1990s suggested a variety of other scenarios to explain the sub-Saharan landscape of today. Fairhead and Leach (1995, 1996), for instance, found that forest islands in northern Guinea are not relics of a former, widespread forest but instead were planted and tended by local peoples within a matrix of savanna. Salzmann (2000) found evidence in the pollen record to indicate that savannization in part of West Africa may have been due to a climate change and independent of human activities. Other authors' work challenges the idea of an impending fuelwood crisis (Brookman-Amissah et al. 1980, Lykke 2000, Ribot 1999) while Millington et al. (1992) indicate that other human activities in addition to fuelwood collection may be responsible for changes in forest cover.

In light of the lack of consensus, this study sought to elucidate the relationship between fuelwood consumption and deforestation. Specifically, fuelwood consumption and forest regeneration rates were estimated with the goal of comparing the two to develop an idea of how much land would be necessary to meet fuelwood demands of inhabitants of a village in the sub-Saharan West African nation of Mali.

\section{Correspondence}

Jeff Morton

1029 West Houghton Street

Santa Fe, New Mexico 87505, U.S.A.

jefferymorton@yahoo.com

Ethnobotany Research \& Applications 5:037-044 (2007) 


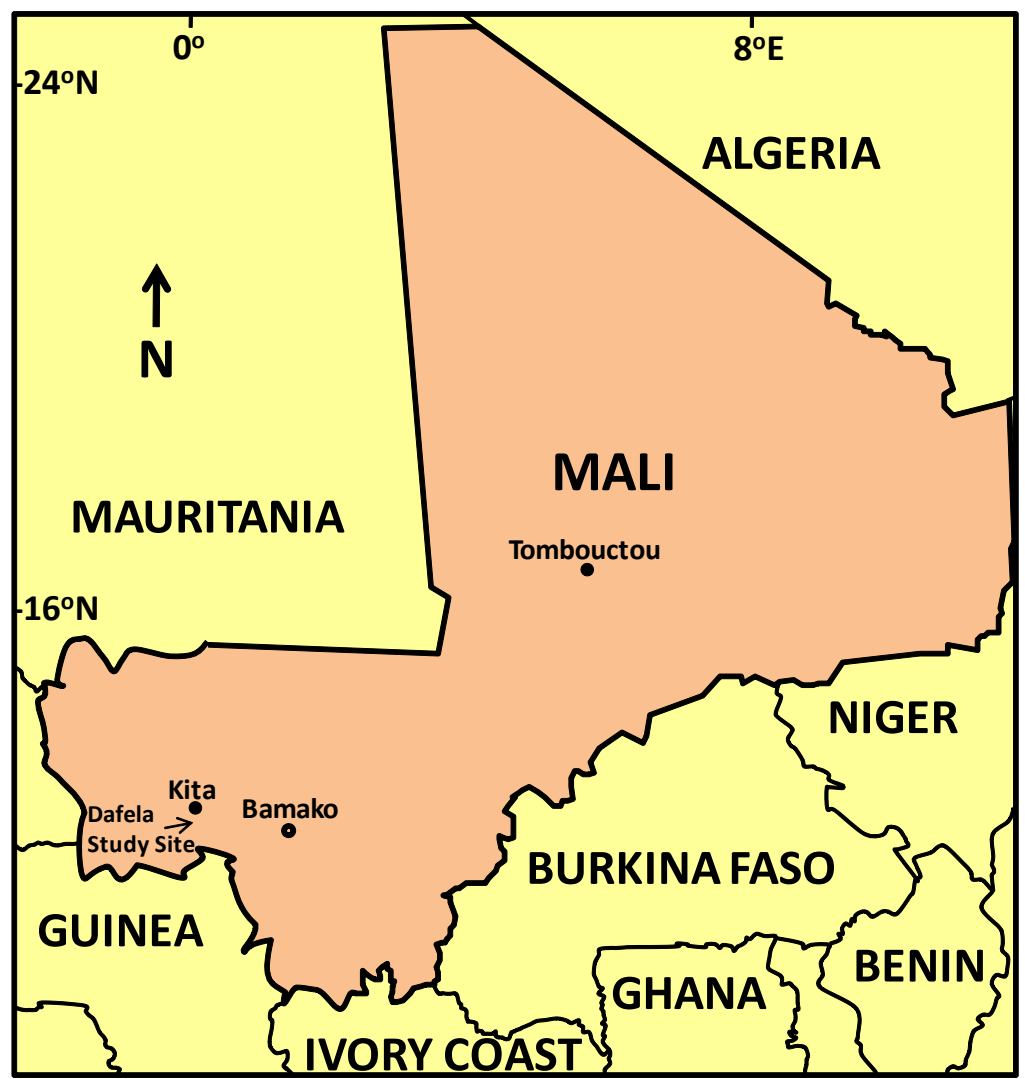

Figure 1. Study site in Dafela, Mali.

The Site

The study was conducted in Dafela, a small, rural village in Mali, West Africa (Figure 1). At last census, its population was 986 . Geographically, the village is located about 10 kilometers southeast of the city of Kita in western Mali, $13.03^{\circ}$ north latitude and $9.29^{\circ}$ west longitude. There are three seasons here: a rainy season from mid-June through October, a cold season from November through January, and a hot season from February up until the first rains in June. From 1996 through 2000, the area received an average of $997 \mathrm{~mm}$ of precipitation per year with August consistently being the wettest month (ASNAAM 2001). The roughly seven months of the cold and hot seasons combined comprise the dry season. Average monthly temperatures range from $17^{\circ} \mathrm{C}$ (in December) to $40^{\circ} \mathrm{C}$ (in April).

Although inconsistently described in the literature, the area is best described as a Sudanian savanna woodland. This ecosystem type is characterized by a long dry season, only one growing season, an open canopy of deciduous or semi-deciduous trees reaching more than $8 \mathrm{~m}$. in height, and a ground stratum dominated by grasses (Archibold 1995). Species highlighted as characteristic within the vegetation zone are Annona spp., Combretum spp., Piliostigma thonningii (Schumach. \& Thonn.) Milne-Redh., and Terminalia spp. (Ghazanfar 1989). Termites are the main decomposers in this system, and ants, although typically feeding on other insects and eggs and not serving as agents of decomposition, aerate the soil. This can be particularly important in areas where the lateritic clays in the soil have become partially impervious; compaction due to the hooves of grazing, domesticated animals is one reason for imperviousness (Archibold 1995).

\section{Background}

The people of Dafela are subsistence-level farmers. Millet is the primary crop. While there is a variety in cultivation regimes due to individual site differences, a common agricultural rotation consists of cultivating land for roughly five years followed by leaving the land fallow for seven years before it is cleared and planted again. Fields are dotted with trees left for shade and secondary, non-timber products. The most frequently occurring field tree species in agricultural plots visited during this study was shea or karité, Vitellia paradoxa Gaertn. \& Hepper. (Sapotaceae). The tree is of importance because of the oil that can be extracted from its seeds, which is a staple in local diets.

Women cook and heat water for bathing and other uses when necessary. Fuelwood collection is the sole responsibility of each adult woman. Children may contribute to collection activities, but only adult women (i.e., wives of adult males associated with the household) maintain woodpiles. Each woman's woodpile is distinct, and wood is continually pulled from the pile. Fuelwood is replenished when branches and stems collected from plots adjacent to agricultural fields and are added to the piles.

\section{Methodology}

\section{Fuelwood Consumption}

Fuelwood consumption was estimated by recording the fuelwood use of four different households in Dafela over the course of a week. For three of these four households, this weekly measurement was made twice. A household is here defined by the collection of women who share cooking responsibilities and the men and children they feed. A typical household would consist of a husband and wife (or wives, as polygyny is practiced in Mali), one or more grown sons and their families, and any younger unmarried children. The households sampled were not selected randomly. Because the process of monitoring fuelwood consumption was somewhat intrusive, I chose to monitor the consumption rates of families which were better known to me and thus more willing to be cooperative.

Fuelwood consumption data collection was modeled after Abbot and Homewood (1999). First, all of the women responsible for cooking and heating water for each house- 
hold were identified. Then, these women were asked to show me all of the places where they stored wood they used for fuel. All of the wood was then weighed to the nearest $0.01 \mathrm{~kg}$ using a hanging scale. Women were then asked to agree to set any wood collected from the fields during the week that I was monitoring their fuelwood use and to not add it to the pile of weighed wood or use it until I had weighed it.

I then visited the households every day during the week and weighed all fuelwood brought from the field by any of the women of the household. Finally, all wood for all women of the household was then reweighed at the end of the week. Fuelwood consumed by the household for the week was then calculated by the following formula:

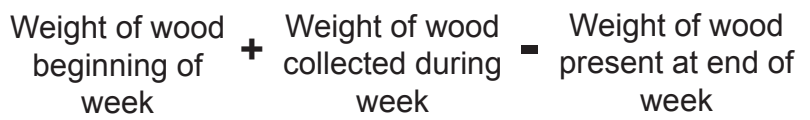

This value for fuelwood consumed was then used to estimate fuelwood consumption per person by dividing the total household's weekly consumption rate and dividing by the number of non-infants within the household. Raw household data was used in a regression analysis to see if an equation predicting fuelwood consumption based upon the number of people in a household could be established with an alpha $=0.05$. Data were analyzed with JMP 5.1.2 software (SAS Institute Inc. 2003).

\section{Fuelwood Supply}

Fuelwood supply was calculated by estimating biomass accumulation for the area. This was done by establishing an inventory plot within two hectares of former agricultural land that had been left fallow for five years. A systematic grid design (Avery \& Burkhart 1994) was established within the fallow. Twenty, $100 \mathrm{~m}^{2}$ circular subplots (radius $=5.64 \mathrm{~m}$ ) were situated within the 2 ha inventory plot resulting in a total inventoried area of $2000 \mathrm{~m}^{2}$, or $5 \%$ of the 2 ha fallow. The foci of the subplots were spaced at intervals of $33.33 \mathrm{~m}$ from north to south and $40 \mathrm{~m}$ from east to west. A full inventory of all trees with stems greater than $10 \mathrm{~cm}$ diameter at breast height ( $\mathrm{dbh}$ ) within the inventory subplots was conducted. Species, dbh, total tree height, tree species and stem taper were recorded. Species were identified with the aid of von Maydell's (1983) woody plant guide.

After completion of the inventory, the three most frequently encountered fuelwood species (Terminalia macroptera Guill. \& Perr., Cassia sieberiana DC., and Combretum glutinosum Perr.) were selected, and three individuals of each species were then felled (T. macroptera: T1, T2 and T3; $C$. sieberiana: C1, C2 and C3; and C. glutinosum: Z1, Z2 and Z3). These three species accounted for roughly $48 \%$ of all individuals in the inventory plot. The trees were then sectioned and weighed in the field (wet weights).

Cookies from the main stem at breast height were then taken from each of the felled nine trees. The volume of the cookies was estimated by treating each as a cylinder. Average diameter for each cookie was taken as the average of two perpendicular diameters of the cookie. Average thickness reflects the average of four measurements of the cookie, each 90 degrees from the previous. The cookies were brought back to the lab and dried for two weeks at $85^{\circ} \mathrm{C}$. The cookies were weighed, and allometric equations correlating volume with dry weight by species were developed. An average dry weight per unit volume (cc) across all species was then calculated.

This average dry weight per volume value was then applied to the estimated standing volume within the inventory subplots to establish a standing biomass. The volumes of the standing tree stems were calculated assuming a conical shape of the bole where the tree dbh is taken as the base of the cone (therefore underestimating standing volume since the base of the stem from ground level to $\mathrm{dbh}$ is not included in the calculation). This then gives an estimate of the mass accumulated for each inventory sub-plot over the five years. Yearly averages for each sub-plot were calculated by dividing by five. These yearly mass accumulation figures were then summed to estimate total woody biomass accumulation for the sub-plots. This value was then scaled up; since the sub-plots represent a $5 \%$ cruise of the 2 ha plot, or 0.1 ha in area, the biomass accumulation value was multiplied by 10 to estimate woody biomass accumulation per ha per year. Trees that pre-dated the last land clearing (i.e., were of dominant canopy stature) were excluded from this calculation.

\section{Results}

\section{Fuelwood Consumption}

Total weekly fuelwood consumption values are presented in Figure 2. Estimated fuelwood consumption per person per year based upon each household's observed consumption is presented in Table 1. The average amount of fuelwood consumed per person per week is 7.29 kilograms while the average weight of fuelwood consumed per person annually is 379.97 . Given the village's population of 986 , this data estimates that 373,619 kilograms of fuelwood are consumed by the village each year.

Linear regression analysis yielded a p-value of 0.74 . Quadratic and cubic analyses produced p-values of 0.81 and 0.86 respectively. With an alpha of 0.05 , it is clear that a statistically significant relationship between number of persons in a household and the amount of wood consumed by the household in a week could not be established. This is at least in part due to the amount of fuelwood consumed by the Cemogoba household during the first week that they were monitored (Cemogoba I).

\section{Forest Regeneration}

The bulk densities of the nine trees selected for allometric analysis are listed in Table 2. I calculated the average bulk density of the three species to be $0.622 \mathrm{~g} / \mathrm{cc}$. Based upon 


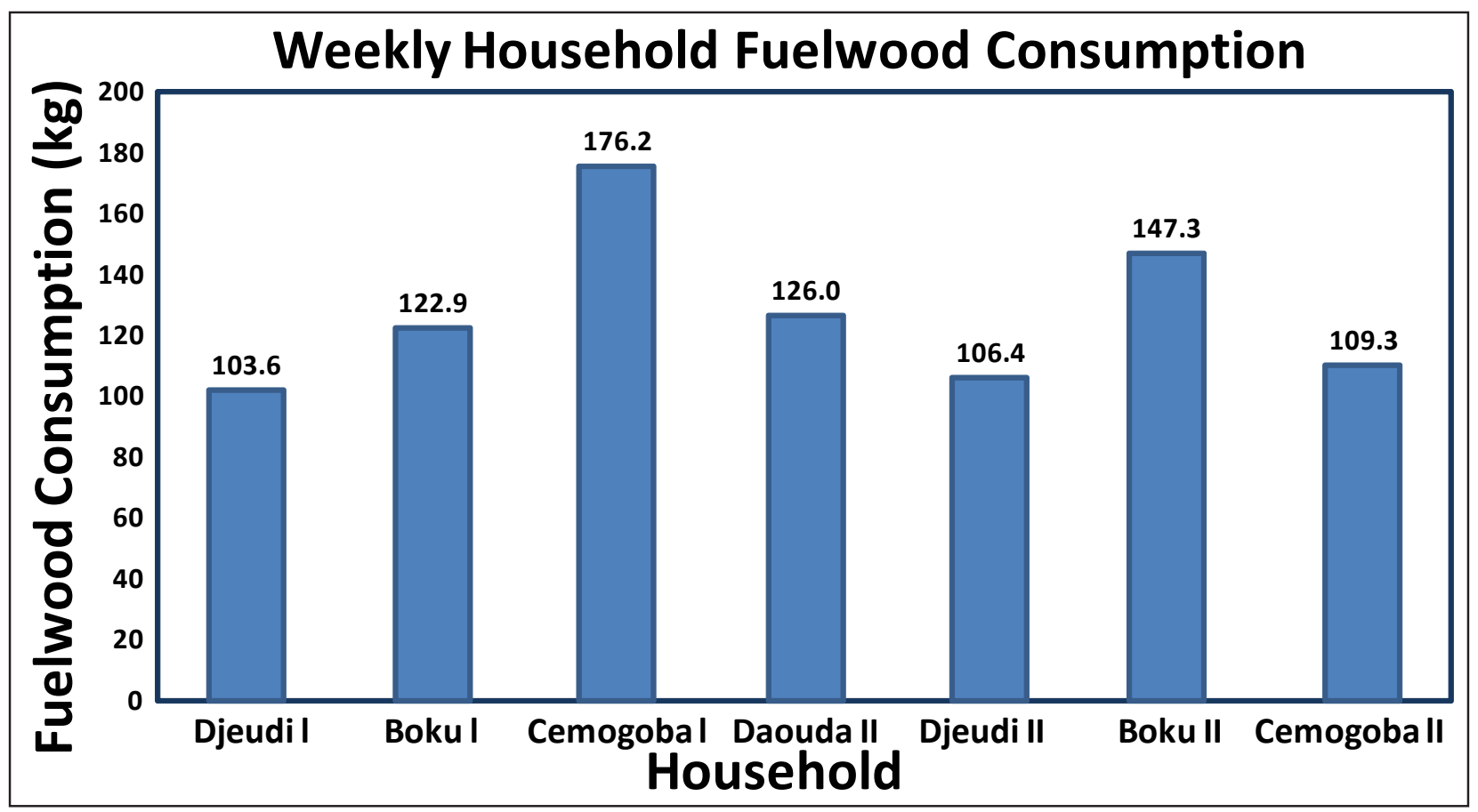

Figure 2. Total weekly fuelwood consumption in households at Defala, Mali.

the estimates of standing wood volume after the five-year fallow period, the woody biomass accumulation rate of the sum of the sub-plots was calculated to be $1,659 \mathrm{~kg} / \mathrm{ha} / \mathrm{year}$ (Table 3).

\section{Discussion}

Households sampled in this study were not randomly selected. While this could have introduced bias into the data, I do not feel that this was the case. I did not perceive any attempt on the parts of the families to tailor data to meet what they felt were my expectations. Further, the benefit of having cooperative households who were willing to take time out of their days to point me to any fuelwood they had collected and to agree to not use any fuelwood that had not been previously weighed by me (i.e., brought back from the field that day) outweighed the benefits of a random sample.

Table 1. Per capita fuelwood consumption at Dafela, Mali.

\begin{tabular}{|l|c|c|c|c|}
\hline Household & $\begin{array}{l}\text { Fuelwood consumption } \\
\text { (kg/week) }\end{array}$ & $\begin{array}{l}\text { People in } \\
\text { household }\end{array}$ & $\begin{array}{l}\text { Fuelwood consumption } \\
\text { (kg/person/week) }\end{array}$ & $\begin{array}{l}\text { Fuelwood consumption } \\
\text { (kg/person/year) }\end{array}$ \\
\hline Djeudi I & 103.59 & 18 & 5.76 & 300.09 \\
\hline Boku I & 122.91 & 22 & 5.59 & 291.32 \\
\hline Cemogoba I & 176.21 & 16 & 11.01 & 574.25 \\
\hline Daouda II & 125.98 & 14 & 9.00 & 469.21 \\
\hline Djeudi II & 106.36 & 15 & 7.09 & 369.74 \\
\hline Boku II & 147.32 & 24 & 6.14 & 320.06 \\
\hline Cemogoba II & 109.25 & 17 & 6.43 & 335.09 \\
\hline Mean & & 18 & 7.29 & 379.97 \\
\hline
\end{tabular}

www.ethnobotanyjournal.org/vol5/i1547-3465-05-037.pdf
While statistical analyses do not support a relationship between the number of people in a household and fuelwood consumption, I have taken the high, mean and low estimates of fuelwood consumption per person within each household to conduct a brief sensitivity analysis. At the high level of consumption in which a person consumes 574.25 $\mathrm{kg}$ of fuelwood per year, each villager would need access to 0.35 ha of fallow land to meet their fuelwood demand given the regeneration rate of $1659 \mathrm{~kg} / \mathrm{ha} /$ year. At the average consumption rate of $380 \mathrm{~kg} /$ person/year, each person needs access to about 0.23 ha of fallow land. Under the low estimate of $291 \mathrm{~kg} /$ person/year, 0.18 ha of fallow could supply the fuelwood demands of one person. Restated, one hectare of land could support the consumption of roughly 6, 4 and 3 people under the low, mean and high estimates of fuelwood consumption respectively (Table 4).

Comparing the mean fuelwood consumption estimate of this study to other published data places the consumption of Dafelans within the ranges of fuelwood consump- 
Table 2. Tree bulk densities sampled at Dafela, Mali.

\begin{tabular}{|c|c|c|c|c|c|}
\hline Cookie & $\begin{array}{l}\text { Dry weight } \\
\text { (g) (Dec 3) }\end{array}$ & $\begin{array}{c}\text { Avgerage } \\
\text { diameter }(\mathrm{cm})\end{array}$ & $\begin{array}{c}\text { Avgerage } \\
\text { thickness }(\mathrm{cm})\end{array}$ & $\begin{array}{l}\text { Volume of cookie } \\
\text { (cc) }\end{array}$ & $\begin{array}{l}\text { Dry density } \\
\text { (g/cc) }\end{array}$ \\
\hline $\mathrm{T} 1$ & 26.20 & 4.85 & 2.5 & 45.3 & 0.58 \\
\hline $\mathrm{T} 2$ & 78.75 & 7.40 & 3.5 & 149.5 & 0.53 \\
\hline T3 & 11.40 & 3.55 & 2.5 & 24.5 & 0.47 \\
\hline C1 & 56.70 & 5.95 & 3.0 & 83.4 & 0.68 \\
\hline $\mathrm{C} 2$ & 16.20 & 3.80 & 2.2 & 24.7 & 0.66 \\
\hline C3 & 32.40 & 4.20 & 3.1 & 42.6 & 0.76 \\
\hline $\mathrm{Z1}$ & 68.20 & 7.55 & 2.5 & 111.9 & 0.61 \\
\hline Z2 & 35.30 & 4.55 & 3.3 & 53.7 & 0.66 \\
\hline Z3 & 30.00 & 4.40 & 3.0 & 45.2 & 0.66 \\
\hline \multicolumn{3}{|l|}{ Species } & $\begin{array}{l}\text { Avgerage dry } \\
\text { density (g/cc) }\end{array}$ & & \\
\hline \multicolumn{3}{|c|}{ Terminalia macroptera Guill. \& Perr. } & 0.52 & & \\
\hline \multicolumn{3}{|c|}{ Cassia sieberiana DC. } & 0.69 & & \\
\hline \multicolumn{3}{|c|}{ Combretum glutinosum Perr. } & 0.64 & & \\
\hline \multicolumn{3}{|c|}{ Avg dry density of all species g/cc } & 0.62 & & \\
\hline
\end{tabular}

Table 3. Woody biomass accumulation in plots samples at Defela, Mali.

\begin{tabular}{|c|c|c|c|}
\hline Plot & Total plot volume $\left(\mathrm{m}^{3}\right)$ & Estimated plot weight (kg) & Growth rate $\left(\mathrm{kg}^{-1}\right)$ \\
\hline$A 5^{*}$ & 0.01 & 8.16 & 1.63 \\
\hline $\mathrm{A} 6^{*}$ & 0.02 & 15.09 & 3.02 \\
\hline A7 & 0.03 & 20.25 & 4.05 \\
\hline A8 & 0.04 & 27.85 & 5.57 \\
\hline A9* & 0.02 & 10.66 & 2.13 \\
\hline $\mathrm{A} 10^{*}$ & 0.05 & 30.41 & 6.08 \\
\hline A11 & 0.04 & 21.85 & 4.37 \\
\hline A12 & 0.16 & 96.76 & 19.35 \\
\hline A13 & 0.09 & 54.05 & 10.81 \\
\hline A14 & 0.03 & 16.16 & 3.23 \\
\hline $\mathrm{A} 15^{*}$ & 0.11 & 65.39 & 13.08 \\
\hline A16 & 0.01 & 8.34 & 1.67 \\
\hline A17 & 0.07 & 44.11 & 8.82 \\
\hline $\mathrm{A} 18^{*}$ & 0.04 & 24.66 & 4.93 \\
\hline A19 & 0.11 & 71.49 & 14.30 \\
\hline A20 & 0.19 & 116.19 & 23.24 \\
\hline A21 & 0.06 & 35.12 & 7.02 \\
\hline A22 & 0.03 & 15.74 & 3.15 \\
\hline A23 & 0.05 & 31.77 & 6.35 \\
\hline A24 & 0.19 & 115.71 & 23.14 \\
\hline \multicolumn{3}{|c|}{ Total growth rate for all sub-plots $(0.1 \mathrm{ha}) \mathrm{kg} / \mathrm{year}$} & 165.96 \\
\hline \multicolumn{3}{|c|}{ Woody biomass accumulation estimate (kg/ha/year) } & 1659.60 \\
\hline
\end{tabular}


Table 4. Sensitivity analysis of estimated fuelwood consumption at three levels of use at Defela, Mali.

\begin{tabular}{|l|c|c|c|c|}
\hline \multirow{2}{*}{ Estimate level } & \multicolumn{2}{l|}{ Consumption rate estimate } & \multicolumn{2}{l|}{ Fuelwood area: Human population } \\
\cline { 2 - 5 } & $\mathbf{( k g / \text { person/week }}$ & $\mathbf{( k g / p e r s o n / y e a r )}$ & (ha/person) & (people/ha) \\
\hline Low & 5.6 & 291 & 0.18 & 5.7 \\
\hline Mean & 7.3 & 380 & 0.23 & 4.4 \\
\hline High & 11.0 & 574 & 0.35 & 2.9 \\
\hline
\end{tabular}

tion rates in other parts of Africa. Abbot and Homewood (1999), for instance, reported a consumption rate of 10.1 $\mathrm{kg} /$ person/week for inhabitants of miombo woodlands in Malawi. Two other studies cited in that publication reported fuelwood consumption rates of $6.8 \mathrm{~kg} /$ person/week and 13 $\mathrm{kg} /$ person/week.

Under the low and high estimates of fuelwood consumption, a family of 18 would need access to a little over 3 and 6 ha of fallow respectively. The village as a whole would consume the equivalent of 173 ha of fallow to meet its fuelwood demand under the low estimate; a little more than 341 ha would be needed by the village under the high estimate. This land requirement range is not unreasonable. Even under the high estimate, a family of 20 could meet its fuelwood needs from a little less than 7 ha of fallow land.

The biomass accumulation rate estimated per this study is in line with other estimates in reasonably similar forest woodland systems. De Troyer (1986) calculated the net above ground productivity of trees and shrubs in a Côte d'Ivoirian savanna to be $2150-7160 \mathrm{~kg} / \mathrm{ha} /$ year. Montalembert and Clément (1983) estimated volumetric increases in woody biomass in a wooded savanna to be between 0.5-2 $\mathrm{m}^{3} /$ ha/year. Given similar wood densities as those calculated in this study, these numbers translate to biomass accumulation rates of $311-1244 \mathrm{~kg} / \mathrm{ha} /$ year.

With regard to the notion that fuelwood consumption leads to deforestation, observations of fuelwood collection does not support the theory. All women observed during the course of the study collected fuelwood by breaking dead limbs and felling snags. Further, they reported that they do not fell live trees for fuelwood. This fuelwood collection technique is corroborated to some degree by Abbot and Homewood (1999) and explicitly by Fairhead and Leach (1996).

The reasons for collecting fuelwood in this manner are several-fold. First, live trees are difficult to cut down, especially when compared to the ease with which snags and dead branches are harvested. Second, live wood cannot be burnt immediately. The wood contains too much moisture and must be dried before it can serve as fuel. Wood from Combretum spp. is said to dry the fastest, and villagers report that it takes a minimum of a week under the hot season sun before it is combustible. Finally, fuelwood collection sites are generally fallow fields that will be cultivated again in the future. Thus, the land that supports a woodlot today will be expected to provide food in the future. The harm associated with the felling of live trees; nutrient de- pletion, soil erosion, increased insolation to the woodland floor; outweighs the need for fuelwood under current consumption and regeneration rates.

\section{Future Research}

\section{Urban Fuelwood Consumption}

This study focused on rural fuelwood consumption and ignored urban fuelwood demand and consumption. Whether urban consumption is related to deforestation is contentious. At least one study points to this as an area of future concern (Millington et al. 1986) while Ribot (1999) challenges the link between urban fuelwood consumption and permanent deforestation. While some research has been conducted on the topic of urban fuelwood (Traore 2001), there is much more work that could be done. Specific areas to explore include urban household consumption rates, methods by which urban fuelwood suppliers collect wood, the mechanisms by which this good is brought to market and the prices charged and paid for fuelwood.

A greater understanding of urban fuelwood markets and mechanisms could prove beneficial in gaining a better comprehension of forest and woodland resource management. For instance, if wood sources are becoming increasingly scarce thus driving up fuelwood prices, it would seem appropriate for the national forest service to raise its forest exploitation tax of 250 CFA. High urban fuelwood prices could also serve as an inducement for rural farmers to begin tree nurseries. This would definitely be the case when potential profits from fuelwood surpass the profits associated with other land uses. In this case, cotton is the highest profit yielding cash crop.

\section{Land Use}

While meeting rural fuelwood demands may not be problematic at present, other concerns present themselves given current land management practices. Fairhead and Leach (1996) note that fuelwood is a by-product of agriculture. Some of the woody biomass cleared during agricultural field preparation is used as fuelwood, but energy is not the motivation for clearings. Millington et al. (1992:57) observe that "(t)he main cause (of the encroachment of savanna vegetation into forested areas) is land clearance for agriculture, timber and construction." To gain a better understanding of the present status of forests and possible future trends, a better base of knowledge regarding land use should be established. 
Land use options in and around Dafela include at least the following five options: sacred groves, uncultivable rocky outcroppings, cultivable land set aside in reserve, agricultural fallows, and active agricultural fields. To better develop resource management plans, a more comprehensive understanding of the prevalence and nature of these land uses is necessary. At a minimum, this requires boundary walks of villages and adjacent lands supplemented by personal interviews with villagers. Remote sensing and aerial photographs could also supply valuable information about the spatial relationship of tracts under different uses and estimates of area under each use. Ultimately, researchers and managers should seek a better understanding of the rationale driving various land use patterns and their geographic extent.

\section{Field Trees}

Field trees can and do serve as a reserve seed source for large, single-stemmed forest tree species. The characteristics that induce farmers to maintain a tree in their field are generally those that are expressed by forest species. Trees are considered desirable in fields if they reach heights and can develop canopies that provide substantial shade. Farmers require shade, under which they can rest and eat the mid-day meal. Women will also use shade trees to shelter small children while they work. Field trees are also typically valued for secondary products as well, such as construction-grade wood and edible fruits (Lykke 2000). Vitellia paradoxa, valued for its oil producing seeds, is the quintessential example.

Individual farmers have distinct preferences, and the trees they maintain within their fields can be reflective of them. For instance, one local farmer keeps a number of mango (Mangifera indica L.) trees in his field. He cares for these trees and sells the fruit as a supplementary source of income. Others may value a particular tree for its medicinal properties and might therefore reserve an individual of this species for that reason. In this way, local inhabitants are preserving seed sources for tree species that evince appreciated characteristics. Lykke (2000) also found this trend in that highly appreciated species perceived to be in decline were protected as field trees.

The composition and selection process of field trees should be studied in greater depth. A broader inventory will give a clearer picture of the expression of farmer preferences. Species found in fields can also be compared to those found in fallow and other land use inventories to determine their overall presence. This information should be complemented by a structured, wider-ranged interview process with the objective of determining how individuals choose which trees will remain in their fields.

\section{Focusing on Individual Species}

Long-term data on species and vegetation changes is generally lacking. In Senegal, however, it is indicated that certain, slower growing species may be declining and in dan- ger of disappearing from certain systems. The analysis strongly suggests a species composition change in favor of shrubby species (Lykke 1998). Aerial photos taken of the area from 1969 to 1989 corroborate the assertion of vegetation change. It should also be noted that the general species composition trend also reflects a shift from highly valued tree species to lesser-valued shrubby species. The author calls for targeting larger trees for conservation while incorporating local preferences (Lykke 2000).

Indications are that this same transition may be occurring in and around Dafela. It is important to note, however, that the Senegalese studies were undertaken within a national park and biosphere reserve. Accordingly, locals who served as respondents generally have a lower degree of control over their forest resources then do Dafelans. It is extremely important to incorporate local information and preferences in any proposed management recommendations for the study site region. Although results of the inventory reflect the same 'degraded' system identified in the Lykke study, it should not be assumed that, if a species composition change is underway, it is not recognized by local populations. It could, in fact, reflect a shift in management practices that mirror altered preferences.

\section{Conclusion}

The data support the notion that woody biomass accumulation is sufficient to meet fuelwood demand in Dafela. At present, women do not make special trips to find and collect fuelwood. Instead, it is a chore done at the end of the farming day just before the women return to village. Harvesting takes little time at all and involves collecting dead branches and small dead trees. Live trees are not felled for fuelwood. None of the women who took part in this study felt that fuelwood supplies were inadequate.

Although fuelwood is not perceived as scarce and does not result in deforestation, fuelwood collection within this system may not be wholly benevolent. The collection of dead, woody biomass for fuelwood does remove nutrients from the system. Archibold (1995:83) cites that the "quantity of nutrients stored in the above-ground biomass accounts for the greatest proportion of the nutrient capital in savanna vegetation." To what degree the woodland is impacted, and whether or not impact translates into direct affects on vegetation growth and/or species composition is unknown.

\section{Acknowledgements}

There are many people to whom I owe thanks for their help in realizing this paper. I would first like to thank my academic advisors Dr. Mark S. Ashton and Dr. Thomas G. Siccama. I also extend my gratitude to James Bryan who helped me develop the idea and proposal for this study. I sincerely appreciate the funding for this project provided by the Tropical Resources Institute of Yale University's School of Forestry and Environmental Studies, the Council on African Studies of the Yale Center for International and Area Studies via the George N. and Mary Lindsay Fellowship for 
Research in Africa, and the Carpenter/Sperry/Mellon Student Research Award.

I am greatly indebted to my in country collaborators. Thank you to the U.S. Peace Corps, Mali, especially to M. Jean Dakou and M. Oumar Cisse, for their support. Special thanks also go to the PC Volunteers Seraphima Shulman and Lesley Keith. I appreciate the time and information offered by M. Mamadou Keita of Agence pour la Sécurité de la Navigation Aérienne en Afrique et à Madagascar, Kita Bureau and M. Seydou Traore, Director General of BEAGGES, Bamako. Finally, I offer my sincerest gratitude to the inhabitants of Dafela for their hospitality and cooperation. I would to specifically recognize the chief of the village, Boku Sidibe and his family, Daouda Sidibe and his family, and the families of Djeudi Sidibe and Cemogoba Sidibe.

\section{Literature Cited}

Abbot, J. \& K. Homewood. 1999. A history of change: causes of miombo woodland decline in a protected area in Malawi. Journal of Applied Ecology 36:422-433.

ASNAAM 2001. Agence pour la Sécurité de la Navigation Aérienne en Afrique et à Madagascar. Kita Bureau.

Archibold, O.W. 1995. Ecology of World Vegetation. Chapman and Hall, London.

Avery, T.E. \& H.E. Burkhart. 1994. Forest Measurements, 4th ed. McGraw Hill Inc., New York

Brookman-Amissah, J., J.B. Hall, M.D. Swaine \& J.Y. Attakorah. 1980. A re-assessment of a fire protection experiment in North-Eastern Ghana savanna. Journal of Applied Ecology 17:85-99.

De Troyer, C. 1986. Desertification control in the Sudanian and Sahelian zones of West Africa - Better Management of the Renewable Resource Base. Forest Ecology and Management 16: 233-241.

Eckholm, E. 1975. The Other Energy Crisis: Firewood. Worldwatch Paper 1. Worldwatch Institute.

Fairhead J. \& M. Leach. 1995. False forest history, complicit social analysis: Rethinking some West African environmental narratives. World Development 6(23):1023-1035.

Fairhead, J. \& M. Leach. 1996. Misreading the African Landscape. Cambridge University Press, Cambridge.

Ghazanfar, S.A. 1989. Savanna Plants of Africa. London: Macmillan Publishers Ltd.

Lykke, A.M. 1998. Assessment of species composition change in savanna vegetation by means of woody plants' size class distributions and local information. Biodiversity and Conservation 7:1261-1275.
Lykke, A. M. 2000. Local perceptions of vegetation change and priorities for conservation of wody-savanna vegetation in Senegal. Journal of Environmental Management 59:107120.

Maiga, A. 1999. Resources forestieres naturelles et plantations, Cas du Mali. CEFAO Programme Partenariat (19982000) Projet GCP/INT/679/EC.

Millington, A.C., P.J. Styles \& R.W. Critchley. 1992. Mapping forests and savannas in sub-Saharan Africa from advanced very high resolution radiometer (AVHRR) imagery. Pp. 37-62 in Nature and Dynamics of Forest-Savanna Boundaries. Edited by Furley J. Proctor \& J.A. Ratter.Chapman and Hall, London.

Montalembert, M.R. \& J. Clément. 1983. Fuelwood Supplies in the Developing Countries. Food and Agriculture Organization of the United Nations, Rome.

Renes, G.J.B. 1991. Regeneration capacity and productivity of natural forest in Burkina Faso. Forest Ecology and Management 41:291-308.

Ribot, J. 1999. A history of fear: Imagining deforestation in the West African dryland forests. Global Ecology and Biogeography 8:291-300.

SAS Institute Inc. 2003. JMP 5.1. SAS Institute Inc., Cary, NC.

Salzmann, U. 2000. Are modern savannas degraded forests?-A Holocene pollen record from the Sudanian vegetation zone of NE Nigeria. Vegetation History and Archaeobotany $9: 1-15$

Steentoft, M. 1988. Flowering Plants in West Africa. Cambridge University Press, Cambridge.

Sumberg, J. \& M. Burke. 1991. People, trees and projects: A review of CARE's activities in West Africa. Agroforestry Systems 15:65-78.

Traore, S. 2001. Director General, BEAGGES; Bamako, Mali. personal communication.

UNFAO. 2001. United Nations Food and Agriculture Organization. www.fao.org/forestry.

USAID. 2001. United States Agency for International Development. www.usaid.gov.

von Maydell, H.J. 1983. Arbres et Arbustes du Sahel: Leurs caractéristiques et leurs utilisations. Deutsche GesseIlschaft für Technische Zusammenarbeit (GTZ). Eschborn.

White, F. 1983. The Vegetation of Africa. United Nations Educational, Scientific and Cultural Organization, Paris. 